\title{
PENURUNAN SIMPANAN KARBON ORGANIK TANAH PADA HUTAN TANAMAN Shorea leprosula Miq. MUDA DI NGASUH, KABUPATEN BOGOR
}

\author{
Decrease in Soil Organic Carbon Stock on Young Shorea leprosula Miq. Plantation \\ in Ngasuh, Bogor District \\ Harris Herman Siringoringo \\ Pusat Penelitian dan Perkembangan Konservasi dan Rehabilitasi \\ Jl. Gunung Batu No. 4 Kotak Pos 165, Bogor 16118 \\ Telp. 0251-8633234, Faks. 0251-8638111 \\ E-mail: ringobogor@gmail.com
}

Naskah masuk : 16 Desember 2013; Naskah diterima : 30 Mei 2014

\begin{abstract}
This research presents information on the influence of a young Shorea leprosula Miq. plantation on soil organic carbon (SOC) within a very high weathered Ferralsols soil type. The measurement was performed twice $\left(T_{1}\right.$ and $\left.T_{2}\right)$, in a 4-year time period after land preparation and planting. This research was performed in Forestry Resort of Ngasuh, Bogor District. The results showed that the cumulative SOC stock resulted a significant decrease at 0-20 $\mathrm{cm}(p<0,05)$ soil depth and it played an important role as a source of $\mathrm{CO}_{2}$ emission, i.e. contributed by 3.35 ton $\mathrm{C} / \mathrm{ha}$ from 55.23 to 51.88 ton C/ha, rating of loss by 0.87 ton C/ha/year $\left(1.58 \%\right.$ year ${ }^{-1}$ ) or equating to 3.19 ton $\mathrm{CO}_{2} /$ halyear loss from soil to the atmosphere. The results concluded that the SOC stock may decrease by way of decreasing on organic matter (litter) input from the plantation to the mineral soil at very high decomposition rate.
\end{abstract}

Keywords: Soil organic carbon stock, ferralsols, slow growing tree species, litter input, equivalent soil mass

\begin{abstract}
ABSTRAK
Penelitian ini menyajikan informasi pengaruh hutan tanaman jenis pohon tumbuh lambat Shorea leprosula Miq muda terhadap perubahan simpanan karbon organik tanah (SOC) pada tipe tanah sangat terlapuk Ferralsols. Vegetasi awal berupa hutan sekunder. Pengukuran dilakukan dua kali, di dalam periode waktu empat tahun setelah penyiapan lahan dan penanaman, dengan menggunakan pendekatan massa tanah setara. Penelitian dilaksanakan di Resort Polisi Hutan (RPH) Ngasuh, Kabupaten Bogor. Hasil penelitian menunjukkan bahwa simpanan SOC kumulatif mengalami penurunan yang signifikan pada kedalaman $0-20 \mathrm{~cm}(\mathrm{p}<0,05)$ dan berkontribusi sebagai sumber emisi, sebesar 3,35 ton $\mathrm{C} /$ ha dari 55,23 ke 51,88 ton C/ha, dengan laju kehilangan sebesar 0,87 ton $\mathrm{C} /$ ha/tahun $(1,58 \%$ per tahun), atau setara dengan emisi karbon dioksida $\left(\mathrm{CO}_{2}\right)$ ke atmosfer sebesar 3,19 ton $\mathrm{CO}_{2} /$ ha/tahun. Hasil ini menyimpulkan bahwa simpanan SOC di Ngasuh menurun dengan penurunan pasokan serasah dari hutan tanaman Shorea leprosula ke dalam mineral tanah dan laju dekomposisi serasah yang tinggi.
\end{abstract}

Kata kunci : Simpanan karbon organik tanah, ferralsols, pohon tumbuh lambat, pasokan serasah, massa tanah setara

\section{PENDAHULUAN}

Tanah berperan sangat penting dalam dinamika karbon (C) pada biosfer (Moreno, 2004) dan mempunyai potensi besar menjadi sumber atau penyimpan $\mathrm{C}$ atmosfer (Mendham et al., 2003) karena tanah menyimpan sekitar $81 \%$ C pada ekosistem daratan (The Word Bank, 2012). Karbon tanah atau lebih tepat disebut sebagai karbon organik tanah (soil organic carbon SOC), karena seba-gian besar karbon tanah berupa bahan organik, adalah penting tidak hanya sebagai indikator utama kesuburan tanah atau produktivitas dan kesinambungan ekosistem daratan, tetapi juga merupakan komponen penting dalam siklus C global (Mini \& Rao, 2011; Chen et al., 2004). Keberadaannya mempunyai dampak pada iklim global pada masa mendatang (Govers et al., 2013). Sebagai gudang C (C pool) dengan kapasitas menyimpan dan melepaskan $\mathrm{C}$ organik terbesar pada daratan, tanah berinteraksi secara kuat dengan perubahan komposisi atmosfer, iklim, dan penutupan lahan (Jobaggy \& Jackson, 2000). Oleh sebab itu, perubahan jumlah SOC 
(menurun atau meningkat) pada lahan dapat berpengaruh signifikan secara global dan dapat mengurangi atau meningkatkan perubahan iklim (Mendham et al., 2003).

Konvensi Kerangka Kerja PBB tentang Perubahan Iklim (UNFCCC) mengakui pentingnya hutan tanaman sebagai pilihan mitigasi gas rumah kaca, serta kebutuhan untuk memantau, melestarikan, dan meningkatkan simpanan $\mathrm{C}$ daratan (Updegraff et al., 2004). Hutan tanaman dapat memainkan peran yang efektif dalam menyeimbangkan tingkat karbon dioksida $\left(\mathrm{CO}_{2}\right)$ atmosfer dengan menangkap dan menyimpan $\mathrm{C}$ dalam biomassa dan tanah (Akbarinia et al., 2012) di satu sisi dan produksinya dapat mengurangi tekanan pada penebangan pohon dari hutan alam di sisi lain, dan dengan demikian memberikan kontribusi untuk konservasi hutan alam (Kaul et al., 2010).

Gudang SOC (SOC pool) ditentukan oleh keseimbangan antara pasokan $\mathrm{C}$ dan kehilangan SOC selama dekomposisi (Jandl et al., 2007). Pasokan SOC yang langsung dari tanaman terjadi melalui jatuhan serasah, eksudat akar (root exudation - proses pelepasan C labil dari akar halus yang hidup ke dalam tanah), akar mati, dan herbivora di bawah dan di atas tanah (Bird et al., 2001). Sementara, kehilangan SOC adalah hasil dari degradasi bahan organik oleh mikroba, eluviasi, kehilangan larutan, dan erosi (Entry \& Emmingham, 1998). Laju sekuestrasi/penyerapan SOC dan besaran serta kualitas simpanan C tergantung pada interaksi yang kompleks antara iklim, tanah, jenis pohon dan pengelolaan, dan komposisi kimia dari serasah yang ditentukan oleh spesies pohon yang dominan (Lal, 2005a).

Pengaruh pembangunan hutan tanaman pada simpanan SOC berbeda di antara jenis pohon yang satu dengan yang lainnya, baik dalam produksi biomassa, konsentrasi hara pada jaringan, maupun pengaruhnya terhadap kualitas tanah (Lal, 2005a). Pemilihan jenis mempunyai pengaruh langsung terhadap potensinya untuk sekuestrasi (Moura-Costa, 1996). Jenis pohon tumbuh cepat (fast growing tree species) misalnya, dapat mengakumulasi $\mathrm{C}$ pada suatu laju yang tinggi, terutama bila ditanam pada lahan pertanian dengan kandungan $\mathrm{C}$ yang rendah. Namun sebaliknya, masa rotasi pemanenannya yang singkat cenderung mengurangi pentingnya ekosistem dalam sekuestrasi C jangka panjang. Dalam hal ini, tanah dapat menjadi suatu bagian penyimpan $\mathrm{C}$ yang penting jika dikelola dengan baik (Madeira et al., 2002). Sebaliknya, jenis pohon tumbuh lambat (slow growing tree species) menahan $\mathrm{C}$ untuk waktu panjang selama satu siklus pertumbuhan dan dapat meningkatkan arti pentingnya ekosistem dalam sekuestrasi C jangka panjang (Moura-Costa, 1996). Tapi sayangnya, informasi mengenai pengaruh pembangunan hutan tanaman jenis pohon tumbuh lambat terhadap keberadaan simpanan SOC terutama pada fase awal pertumbuhannya masih jarang dipublikasikan.

Penelitian ini bertujuan untuk mendapatkan informasi tentang besaran simpanan SOC dan laju akumulasi dan atau laju kehilangan pada jenis pohon tumbuh lambat Shorea leprosula Miq. pada tipe tanah sangat terlapuk Ferralsols.

\section{METODOLOGI}

\section{A. Lokasi dan Waktu Penelitian}

Penelitian dilaksanakan pada demplot hutan tanaman S. leprosula yang baru dibangun (newly establishment) pada kawasan seluas lima hektar pada petak 17A, di RPH Ngasuh $\left(6^{0} 33^{\prime}-6^{0} 34^{\prime}\right.$ LS, $106^{\circ} 25^{\prime}-106^{\circ} 26^{\prime}$ BT), Bagian Kesatuan Pemangkuan Hutan (BKPH) Jasinga, wilayah kerja Kesatuan Pemangkuan Hutan (KPH) Bogor, Perum Perhutani Unit III Jawa Barat dan Banten.

Topografi areal penelitian termasuk kategori bukit bergelombang (rolling hills) dengan kemiringan lereng $0^{\circ}-20^{\circ}$, dan ketinggian tempat $250 \mathrm{~m}$ di atas permukaan laut. Kondisi iklim lokasi penelitian adalah tipe $\mathrm{B}$ dengan rata-rata curah hujan tahunan $3.148 \mathrm{~mm}$ selama 5 tahun sejak tahun 1995 hingga 1999 yang tercatat di Stasiun Klimatologi Cikopomayan, Nanggung, Kecamatan Leuwliang, Bogor. Vegetasi asli (baseline vegetation) lokasi penelitian diidentifikasi sebagai hutan sekunder yang didominasi oleh jenis Maesopsis eminii (kayu afrika) dan Schima wallichii (puspa) dengan tinggi rata rata $5,8 \mathrm{~m}$ pada awal penelitian. Tipe tanah pada areal penelitian adalah Haplic Ferralsols (Siregar et al., 2003), berdasarkan pada Word Reference Base (FAO/ISRIC/ISSS, 1998) atau Soil Survey Staff (1999). Karakteristik profil tanah adalah kandungan liat tinggi (77-81\%) dan kandungan basa-basa yg dipertukarkan rendah ; lapisan atas tanah warna hitam kecokelatan (brownish black) (10YR 3/2) dan lapisan bawah tanah warna coklat (brown) $(7,5 \mathrm{YR} 4 / 3)$ hingga oranye (5YR 6/6) dalam sistem warana Munsell; struktur tanah lemah (weak), sedang (medium), dan butiran (granular). 
Pembangunan demplot $S$. leprosula menerapkan praktik-praktik pengelolaan hutan tanaman sebagaimana pada umumnya. Penyiapan lahan dilakukan dengan cara tebang habis (clearcutting) vegetasi berupa pohon dan belukar. Setelah penebangan, bibit $S$. leprosula ditanam dengan sistem jalur dan pola monokultur dengan jarak tanam $2 \mathrm{~m} \times 3 \mathrm{~m}$ dan lobang tanam $30 \mathrm{~cm} \times$ $30 \mathrm{~cm}$ x $30 \mathrm{~cm}$. Penyiangan (weeding) dilakukan dua kali dalam setahun. Pemangkasan (prunning) dan pemotongan cabang batang (singling) dilakukan satu kali dalam setahun. Pada umur 46 bulan pada tahun 2005 , S. leprosula mencapai tinggi rata-rata $2,5 \mathrm{~m}$.

\section{B. Bahan dan Alat Penelitian}

Demplot hutan tanaman S. leprosula digunakan sebagai obyek penelitian untuk pengambilan contoh-contoh tanah dalam dua seri waktu. Alatalat penelitian yang digunakan di lapangan adalah: GPS, chainsaw, munsell, meteran, golok, cangkul, ring sampel, gunting, buku tulis, kantong plastik, dan tali plastik. Peralatan yang digunakan di laboratorium antara lain adalah : $\mathrm{NC}$ Analyzer, oven, willey mill, vibration mill, timbangan analitik, desikator, dan gelas ukur.

\section{Metode Penelitian}

Penelitian ini dilaksanakan dalam dua seri waktu pengambilan contoh tanah dalam periode 46 bulan (4 tahun) di dalam demplot yang sama. Pengambilan contoh tanah pada survei awal (T1) dilaksanakan pada bulan November 2001, yaitu setelah penyiapan lahan/satu bulan sebelum penanaman $S$. leprosula. Sementara pengambilan contoh tanah pada survei terakhir pada akhir September 2005 (T2).

\section{Disain plot dan metode pengambilan con- toh tanah}

Plot pengambilan contoh tanah terdiri dari empat blok $(20 \mathrm{~m} \times 30 \mathrm{~m})$ yang ditentukan secara acak di dalam demplot hutan tanaman $S$. leprosula (5 ha). Pada setiap blok ditentukan sebanyak 10 titik pengambilan contoh tanah (sampling subunit) secara sistematik. Sementara, pengambilan contoh tanah pada plot vegetasi awal/baseline vegetation terdiri dari 10 subplot $(10 \mathrm{~m} \times 10 \mathrm{~m})$ yang ditentukan secara acak di dalam plot hutan sekunder (5 ha). Pada masingmasing subplot ditentukan sebanyak empat titik pengambilan contoh tanah yang terletak pada ke empat sisi bagian luar petak bujur sangkar.
Pengambilan contoh dalam dua seri waktu yang berbeda pada plot hutan tanaman $S$. leprosula dilakukan pada dua bagian/titik yang berbeda di dalam setiap blok yang sama. Pada umumnya, dalam survei tanah pada lahan bervegetasi terutama untuk keperluan analisis sifat fisik dan kimia tanah, titik awal pengambilan contoh tanah ditentukan pada bagian permukaan tanah yang tidak terganggu. Titik-titik pengambilan contoh tanah pada setiap blok dan seri waktu dinarasikan secara ringkas pada Tabel 1 .

Contoh-contoh tanah diambil pada 40 titik pengambilan contoh (35 titik pada kedalaman 0$30 \mathrm{~cm}$ dan 5 titik pada kedalaman 0-100 cm). Pada kedalaman 0-30 cm, contoh-contoh tanah diambil dari empat lapisan $(n=4)$ kedalaman tanah $(0-5 ; 5-10 ; 10-20$; dan $20-30 \mathrm{~cm})$ pada 35 titik pengambilan contoh. Pada kedalaman 0 $100 \mathrm{~cm}$, contoh contoh tanah diambil dari tujuh lapisan $(\mathrm{n}=7)$ kedalaman tanah $(0-5 ; 5-10 ; 10$ $20 ; 20-30 ; 30-50 ; 50-70 ;$ dan $70-100 \mathrm{~cm}$ ).

Pengambilan contoh tanah yang dibagi dalam beberapa lapisan kedalaman tertentu (fixed depth layers) dimaksudkan untuk memperhitungkan perbedaaan keragaman kandungan SOC pada kedalaman tanah (Don et al., 2007). Perbedaan keragaman kandungan SOC pada kedalaman tanah terjadi karena setiap jenis vegetasi berbeda dalam distribusi akar vertikalnya dan meninggalkan jejak yang berbeda pada distribusi kedalaman SOC (Lorenz \& Lal, 2005). Survei C tanah biasanya mempertimbangkan kedalaman tanah tetap, umumnya satu meter (Jobbagy \& Jackson, 2000). Penelitian global berdasarkan unit vegetasi (Post et al., 1982) dan unit taksonomi tanah (Eswaran et al., 1993; Batjes, 1996) menunjukkan bahwa simpanan SOC adalah sekitar 1500-1600 Pg C (1 Pg = satu miliar ton) pada kedalaman satu meter pertama.

Contoh-contoh tanah diambil dengan menggunakan sebanyak empat buah ring sampel (sampling rings) pada setiap interval/lapisan kedalaman $0-5$; 5-10; 10-20; 20-30; 30-50 ; 50-70 cm dan sebanyak enam buah ring sampel pada interval kedalaman $70-100 \mathrm{~cm}$. Kemudian, contoh-contoh tanah diambil berurutan mulai dari lapisan teratas hingga lapisan terbawah dengan menggunakan ring sampel tanah dengan volume $100 \mathrm{cc}\left(20 \mathrm{~cm}^{2}\right.$ x $\left.5 \mathrm{~cm}\right)$. Ring sampel ditempatkan secara konsisten di setiap lapisan tanah untuk mendapatkan contoh yang representatif pada setiap kedalaman. Contoh-contoh tanah 
Tabel (Table) 1. Jumlah titik pengambilan contoh tanah pada setiap subplot, kedalaman, dan seri waktu pada plot hutan tanaman $S$. leprosula dan plot vegetasi awal (The number of sampling points in each subplots, soil depths and time series on Shorea leprosula plantation and baseline vegetation plots)

\begin{tabular}{|c|c|c|c|c|c|c|c|}
\hline \multirow[t]{2}{*}{ Plot } & \multirow[t]{2}{*}{ Subplot } & \multicolumn{2}{|c|}{$\begin{array}{l}2001 \\
(\mathrm{~T} 1)\end{array}$} & \multicolumn{2}{|c|}{$\begin{array}{l}2005 \\
(\mathrm{~T} 2)\end{array}$} & \multicolumn{2}{|c|}{$\begin{array}{c}\text { Jumlah titik pengambilan } \\
\text { contoh dalam dua seri waktu } \\
\text { (Number of sampling points in } \\
\text { two time series) }\end{array}$} \\
\hline & & $\mathrm{x}$ & $\mathrm{xx}$ & $\mathrm{x}$ & $\mathrm{xx}$ & $\mathrm{x}$ & $\mathrm{xx}$ \\
\hline Hutan tanaman & $\mathrm{A}$ & 8 & 2 & 8 & 2 & 16 & 4 \\
\hline Shorea leprosula & B & 9 & 1 & 9 & 1 & 18 & 2 \\
\hline \multirow{3}{*}{$\begin{array}{c}\text { (Shorea leprosula } \\
\text { plantation) }\end{array}$} & $\mathrm{C}$ & 9 & 1 & 9 & 1 & 18 & 2 \\
\hline & $\mathrm{D}$ & 9 & 1 & 9 & 1 & 18 & 2 \\
\hline & $\begin{array}{l}\text { Jumlah titik pengambilan contoh } \\
\text { (Number of sampling points) }\end{array}$ & 35 & 5 & 35 & 5 & 70 & 10 \\
\hline \multirow{11}{*}{$\begin{array}{l}\text { Vegetasi awal } \\
\text { (Baseline } \\
\text { vegetation) }\end{array}$} & P1 & 3 & 1 & - & - & 3 & 1 \\
\hline & P2 & 3 & 1 & - & - & 3 & 1 \\
\hline & P3 & 3 & 1 & - & - & 3 & 1 \\
\hline & P4 & 4 & - & - & - & 4 & - \\
\hline & P5 & 4 & - & - & - & 4 & - \\
\hline & P6 & 4 & - & - & - & 4 & - \\
\hline & P7 & 4 & - & - & - & 4 & - \\
\hline & P8 & 3 & 1 & - & - & 3 & 1 \\
\hline & P9 & 4 & - & - & - & 4 & - \\
\hline & P10 & 3 & 1 & - & - & 3 & 1 \\
\hline & $\begin{array}{l}\text { Jumlah titik pengambilan contoh } \\
\text { (Number of sampling points) }\end{array}$ & 35 & 5 & & & 35 & 5 \\
\hline
\end{tabular}

Keterangan (Remarks) : x: kedalaman 0-30 cm (0-30 cm soil depths)

Xx: kedalaman 0-100 cm (0-100 cm soil depths $)$

dari setiap lapisan yang sama dari setiap titik pengambilan contoh dikompositkan (bulked) dan dimasukkan ke dalam kantong plastik untuk keperluan analisis di laboratorium. Jumlah total contoh tanah yang dikumpulkan dalam dua seri waktu adalah sebanyak 350 contoh dari 80 titik pengambilan contoh (70 titik pada kedalaman 0-30 cm pada empat lapisan/horizon tanah ditambah 10 titik pada kedalaman $0-100 \mathrm{~cm}$ pada tujuh lapisan tanah).

\section{Metode penyiapan dan analisis contoh}

Contoh tanah dikering-udarakan kurang lebih selama 7-14 hari hingga beratnya stabil, dan potongan-potongan akar yang terikut dibuang. Selanjutnya berat massa masing-masing contoh tanah yang telah dikering-udarakan $(\mathrm{Wt})$ ditimbang. Kemudian contoh-contoh tanah dihaluskan dengan menggunakan Willey Mill dan disaring dengan ayakan berukuran $2 \mathrm{~mm}$ untuk memisahkan tanah halus $(<2 \mathrm{~mm})$ dari bebatuan (>2 mm). Berat bebatuan (Wg) ditimbang. Kerapatan massa/bulk density (BD) tanah dihitung berdasarkan: volume contoh per lapisan tanah (empat atau enam ring), berat contoh tanah kering udara, dan faktor kadar air tanah halus kering udara (MFf, moisture factor fine soil).

Pengukuran faktor kadar air dari contoh tanah halus kering udara (MFf) dilakukan dengan cara menimbang sekitar $10 \mathrm{~g}$ contoh tanah halus kering udara (Wf) ke dalam wadah (beaker glass ukuran 30-50 ml) yang diketahui bobotnya (Wv1), dan dimasukkan ke dalam oven pada suhu $105^{\circ}$ selama 1 malam, didinginkan ke dalam desikator, dan ditimbang bobot tanah kering oven dan wadah (Wo1). Untuk keperluan analisis C tanah dan penentuan faktor kadar air tanahnya (MFp, moisture factor powder soil), sekitar $20 \mathrm{~g}$ contoh tanah halus yang telah kering udara dihaluskan kembali hingga menjadi bubuk halus (powder) dengan menggunakan Vibration Mill. Analisis kandungan $\mathrm{C}$ tanah menggunakan metode pembakaran (Combustion method) dengan perangkat instrumen $N C$ Analyzer (Sumigraph NC-900, Sumitomo Chemicals LTD). 


\section{Perhitungan}

a. Kerapatan massa tanah

Kerapatan massa/tingkat kepadatan (BD) tanah dinyatakan sebagai massa per satuan volume tanah $\left(\mathrm{g} / \mathrm{cm}^{3}\right.$ atau ton $\left./ \mathrm{m}^{3}\right)$.

$$
\begin{aligned}
& \mathrm{BD}\left(\mathrm{g} / \mathrm{cm}^{3}\right)=(\mathrm{WtWg}) \times(1 \mathrm{Mff})(\text { Ohta, 2001) ..........(1) } \\
& 4 \text { atau } 6 \times \operatorname{Vr}(\mathrm{ml}) \\
& \mathrm{Mff}=\left(\frac{\mathrm{Wv} 1 \mathrm{Wo} 1)}{5 \mathrm{Wf}}\right.
\end{aligned}
$$

Dimana:

$\mathrm{Wt}=$ berat total tanah kering udara (total weight of air-dried soil $),(\mathrm{g})$

$\mathrm{Wg}=$ berat bebatuan (weight of gravel),$(\mathrm{g})$

$\mathrm{Mff}=$ faktor kadar air tanah halus (moisture factor of fine soil)

$\mathrm{Vr}=$ volume ring contoh

$\mathrm{Wf}=$ berat tanah halus kering udara (air dried fine soil weight)

b. Kandungan karbon

$$
\begin{aligned}
& \mathrm{C} \%=\frac{\text { Chasil pengukuran }}{(1 \mathrm{Mfp})}(\text { Ohta, 2001)... } \\
& \mathrm{MFp}=\frac{(\mathrm{Wv1} \text { Wo1 })}{\mathrm{Wp}}
\end{aligned}
$$

Dimana:

Mfp = faktor kadar air tanah bubuk halus (moisture factor of powder soil

$\mathrm{Wp}=$ berat tanah bubuk kering udara (air dried powder soil weight)

$\mathrm{Wv} 1=$ berat wadah dan berat contoh tanah (weight of vessel and soil sample)

Wo1 $=$ berat tanah kering oven $105^{\circ} \mathrm{C}$ dan berat wadah (weight of $105^{\circ} \mathrm{Coven}$-dried soil and vessel)

c. Simpanan karbon tanah

Perhitungan jumlah simpanan SOC pada seri waktu pengambilan contoh awal pada tahun 2001 (T1) (tahun referensi) dihitung sama seperti perhitungan simpanan SOC pada umumnya, yaitu berdasarkan metode pendekatan kedalaman tetap (fixed depth approach) sebagaimana ditunjukkan pada persamaan berikut:

$$
\begin{aligned}
& \text { Simpanan } C \text { tanah }_{\text {kedalaman }}(\mathrm{n})= \\
& \sum_{\mathrm{i}=1} \frac{\mathrm{TH}(\mathrm{i}) \times \mathrm{BD}(\mathrm{i}) \times \mathrm{Cs}(\mathrm{i})}{(1-\mathrm{MFp})}(\text { Ohta, 2001). }
\end{aligned}
$$

Dimana:

Simpanan C tanah ${ }_{\text {kedalaman }}\left(\right.$ Soil C stock depth $\left._{\text {) }}\right)$, ton $/$ ha

$\mathrm{TH}=$ ketebalan lapisan tanah (thickness of each soil layer $),(\mathrm{cm})$

Cs = kandungan karbon tanah (soil carbon content $),(\%)$

Mfp = faktor kadar air tanah bubuk halus (moisture factor of fine powder soil)

$\mathrm{BD}=$ kerapatan massa (bulk density), $\left(\mathrm{g} / \mathrm{cm}^{3}\right)$
Selanjutnya perhitungan jumlah simpanan SOC pada seri waktu pengambilan contoh terakhir tahun 2005 (T2) dikoreksi dengan metode pendekatan massa tanah setara (equivalent soil mass approach) yang disajikan oleh Ellert \& Bettanym (1995) yang kemudian dimodifikasi berdasarkan massa tanah mineral oleh Toriyama et al. (2011) untuk menghindari efek perubahan bahan organik tanah daripada berdasarkan massa tanah keseluruhan (bulk soil mass) sebagaimana yang disajikan Ellert \& Bettanym (1995). Mengingat variabilitas sifat-sifat tanah, massa tanah setara dihitung pada setiap titik pengambilan contoh tanah (Gifford \& Roderick, 2003). Pada seri waktu pengukuran T2, penghitungan simpanan SOC disesuaikan berdasarkan perbedaan pada rerata massa kumulatif fraksi mineral tanah antara seri waktu pengukuran $\mathrm{T} 1$ dan $\mathrm{T} 2$. Rangkaian perhitungan dilakukan berikut di bawah ini.

Massa kumulatif fraksi mineral tanah dihitung dengan menggunakan data tanah pada survei pertama untuk menentukan massa tanah setara.

BDmf $=$ BD BDsom ..............................(6)

$\mathrm{BD} \operatorname{som}\left(\mathrm{g} / \mathrm{cm}^{3}\right)=$ massa bahan organik tanah per volume (mass of soil organic matter per volume)$$
=\mathrm{BD} \times \operatorname{Cs} \times 1,724 \times 10^{-2}
$$

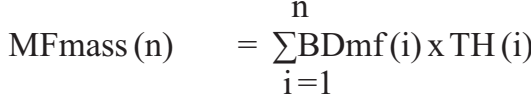

Dimana :

$\operatorname{BDmf}\left(\mathrm{g} / \mathrm{cm}^{3}\right)=$ massa fraksi mineral tanah per volume (mass of soil mineral fraction per volume)

$1,724=$ faktor konversi rasio massa dari $\mathrm{C}$ organik tanah ke bahan organik tanah (conversion factor of mass ratio of soil organic $C$ to soil organic matter) (Pribyl, 2010)

MF mass (ton/ha) = massa kumulatif fraksi mineral tanah hingga lapisan terbawah (cumulative mass of soil mineral fraction to the bottom of nth layer)

$\mathrm{TH}(\mathrm{i})(\mathrm{cm}) \quad=$ ketebalan lapisan tanah (thickness of each soil layer)

Massa tanah setara ( $M F$ mass equivalen) dihitung berdasarkan rasio nilai rerata massa tanah kumulatif pada survei awal (T1) dan survei terakhir (T2) untuk mengontrol nilai koefisien keragaman massa tanah kumulatif pada lokasi penelitian, seperti persamaan (8) berikut:

MFmass equiv $=$ MFmass $_{2 \text { nd }} \mathrm{xM}_{1 \mathrm{st}} \mathrm{x} \mathrm{M}^{-1}$ 


\begin{abstract}
Dimana:
MFmassequiv (ton/ha) $=$ massa setara fraksi mineral tanah pada setiap titik pengambilan contoh (equivalent mass of soil mineral fraction in each sampling subunit)

MFmass2nd (ton/ha) = massa kumulatif fraksi mineral tanah pada pengukuran kedua () pada setiap titik pengambilan contoh (cumulative mass of soil mineral fraction in the second survey in each sampling subunit)

$M 1$ st and $M 2 \mathrm{nd}=$ massa fraksi mineral $(\mathrm{MF})$ pada setiap titik pengambilan contoh $(n=40)$ pada survei pertama dan kedua/terakhir secara berurutan (mean MFmass for the subunit ( $n$ $=40$ ) in the first and second/last survey, respectively).
\end{abstract}

Perhitungan simpanan SOC berdasarkan massa tanah setara dihitung berdasarkan perbedaan antara MF massequiv dan MF mass $2^{\text {nd }}$, seperti persamaan (9) berikut:.

$$
\begin{aligned}
& \operatorname{Cstock}_{\text {mass }}(n)=\operatorname{Cstock}_{\text {depth }}(n)+\text { Cstock mf }(i) \times \\
& {\left[\operatorname{MFmass}_{\text {equiv }}(n)-\operatorname{MFmass}_{2 \mathrm{nd}}(n)\right] \text {. }}
\end{aligned}
$$

d. Laju akumulasi atau kehilangan karbon organik tanah

Laju akumulasi/sekuestrasi atau kehilangan/ pelepasan SOC dihitung berdasarkan selisih antara simpanan SOC kumulatif di antara dua seri waktu pengambilan contoh dalam rentang waktu tertentu dan dinyatakan dalam satuan ton/ha/tahun. Simpanan SOC kumulatif pada kedalaman 0-30 $\mathrm{cm}$ dan 0-100 $\mathrm{cm}$ adalah jumlah simpanan SOC dari setiap lapisan, misalnya pada kedalaman 0-30 $\mathrm{cm}$ adalah jumlah simpanan SOC dari lapisan 0-5, 5-10, 10-20, dan 20-30 cm.

\section{Analisis Data}

Analisis keragaman (ANOVA) digunakan untuk menguji perbedaan nilai rata-rata parameter kerapatan tanah (BD), kandungan SOC, dan simpanan SOC kumulatif pada setiap kedalaman tanah di antara dua seri waktu pengambilan contoh tanah (T1 dan T2). Faktor blok (ulangan) atau titik-titik pengambilan contoh (sampling units) digabungkan (incorporated) sebagai efek acak (random effect). Untuk parameter yang berbeda secara statistik $(\mathrm{p}<0,05)$, nilai rata-rata dipisahkan dengan menggunakan uji perbandingan perbedaan nyata terkecil (Least Significant Difference/LSD). Semua uji statistik dilakukan dengan perangkat lunak JMP Start Statistics (Sall et al., 2005).

\section{HASIL DAN PEMBAHASAN}

\section{A. Kandungan Karbon}

Kandungan karbon organik tanah (SOC) pada plot hutan tanaman S. leprosula pada pengamatan pertama (T1) dan kedua (T2) disajikan pada Tabel 2.

Secara umum kandungan SOC menunjukkan laju gradiasi vertikal pada kedalaman satu meter pertama, dengan nilai tertinggi pada lapisan paling atas $(0-5 \mathrm{~cm})$ dan terendah pada lapisan paling bawah $(70-100 \mathrm{~cm})$. Kandungan SOC umumnya menurun sebagai fungsi dari kedalaman tanah dan distribusi vertikalnya dipengaruhi oleh faktor seperti iklim, tekstur tanah, dan tipe vegetasi (Jobbagy \& Jackson, 2000).

Berdasarkan seri waktu (T1 dan T2), kandungan SOC pada plot hutan tanaman $S$. leprosula cenderung menurun pada kedalaman $0-30 \mathrm{~cm}$ dan berbeda nyata pada lapisan $0-5 \mathrm{~cm}(\mathrm{p}<0,001)$ pada T2. Sementara pada kedalaman 30-100 cm (30-50; 50-70; 70-100 cm), kandungan SOC tidak berbeda nyata $(p>0,05)$ di antara kedua seri pengamatan (Tabel 2, Gambar 1).

Sebagian besar kehilangan jumlah kandungan SOC dengan konversi vegetasi alam ke lahan pertanian disebabkan oleh: penurunan pasokan bahan organik (serasah); peningkatan penguraian residu tanaman; dan pengaruh penyiapan lahan yang menurunkan jumlah perlindungan fisik terhadap penguraian/dekomposisi (Post \& Kwon, 2000). Besaran perubahan kandungan SOC tergantung pada tipe tanah dan vegetasi, dan biasanya mengikuti distribusi kepadatan akar vegetasi yang dominan (Allen et al., 2010). 
Tabel(Table) 2. Nilai rerata kandungan karbon organik tanah (\%) pada plot hutan tanaman S. leprosula berdasarkan waktu pengambilan contoh pada tujuh lapisan tanah (Mean values of soil organic carbon content $(\%)$ of $\mathrm{S}$. leprosula plantation plot based on the sampling time at seven soil layers)

\begin{tabular}{ccccc}
\hline & & \multicolumn{2}{c}{$\begin{array}{c}\text { Kandungan karbon (Carbon content), } \\
\text { C (\%), rerata (Mean) } \pm \text { SD }\end{array}$} & Anova \\
\cline { 3 - 5 } Kedalaman (Depths) & $\mathrm{N}$ & $\mathrm{T} 1$ & $\mathrm{~T} 2$ & $\begin{array}{c}\text { Nilai F } \\
(\text { F- value })\end{array}$ \\
\cline { 3 - 5 } & 40 & $5,85 \pm 0,82(\mathrm{a})$ & $4,83 \pm 0,86(\mathrm{a})$ & 29,71 \\
& & & *** \\
$5-5$ & 40 & $4,30 \pm 0,68(\mathrm{~b})$ & $4,14 \pm 0,68(\mathrm{~b})$ & 1,12 \\
$10-20$ & 40 & $3,58 \pm 0,58(\mathrm{c})$ & $3,46 \pm 0,53(\mathrm{c})$ & 0,93 \\
$20-30$ & 40 & $2,82 \pm 0,48(\mathrm{~d})$ & $2,71 \pm 0,46(\mathrm{~d})$ & 1,05 \\
$30-50$ & 5 & $2,08 \pm 0,33(\mathrm{de})$ & $2,30 \pm 0,24(\mathrm{de})$ & 1,53 \\
$50-70$ & 5 & $1,61 \pm 0,17(\mathrm{e})$ & $1,79 \pm 0,19(\mathrm{e})$ & 2,39 \\
$70-100$ & 5 & $1,25 \pm 0,16(\mathrm{e})$ & $1,40 \pm 0,27(\mathrm{e})$ & 1,11 \\
\hline
\end{tabular}

Keterangan (Remarks):

$1 . * * *=\mathrm{p}<0,001$

2. Nilai rerata di dalam kolom yang sama diikuti huruf yang berbeda adalah berbeda nyata pada taraf $5 \%$ menurut uji HSD-Tukey Kramer, $\mathrm{p}<0,05$ ) (Mean value in the same columns followed by the different letters are significantly different at $5 \%$ level according to Tukey-Krammer HSD test)

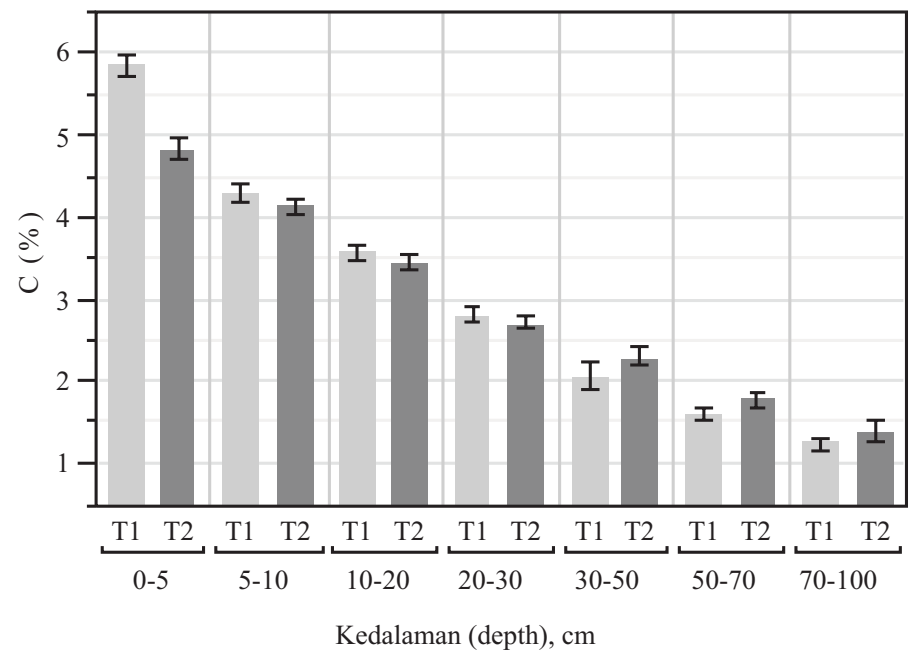

Gambar(Figure) 1. Perbandingan nilai rerata kandungan SOC (C\%) pada plot hutan tanaman Shorea leprosula berdasarkan waktu pengambilan contoh tanah pada tujuh lapisan tanah (Comparison of mean values of SOC content $(\mathrm{C} \%)$ based on the sampling times of seven soil layers)

Hasil penelitian Toriyama et al. (2011) menunjukkan bahwa jumlah akumulasi serasah pada lantai hutan tanaman S. lepro-sula di Ngasuh selama periode waktu tiga tahun pertama menurun dari 7,5 ke 1,9 ton/ha. Semen-tara berdasarkan data hasil analisis, rasio $\mathrm{C} / \mathrm{N}$ bahan serasah/ residu tanaman ( $\mathrm{n}=40$, data tidak ditampilkan) adalah relatif rendah $(13,5)$. kua-litas bahan serasah dengan rasio $\mathrm{C} / \mathrm{N}$ rendah akan lebih cepat terdekomposisi/terurai.
Jumlah dan kualitas pasokan karbon ke dalam tanah merupakan fungsi kehadiran vegetasi (Baldock \& Skjemstad, 1999). Peningkatan produksi biomassa tanaman kemungkinan akan meningkatkan SOC, sementara penambahan residu tanaman dengan rasio karbon: nitrogen $(\mathrm{C}: \mathrm{N})$ yang lebih tinggi dan nitrogen: lignin yang lebih rendah akan mengurangi laju dekomposisi residu dan kemungkinan dapat mempertahankan atau meningkatkan karbon organik tanah (Walcott et 
al., 2009). Laju dekomposisi dikontrol oleh kondisi tanah (kelembaban, suhu, dan kecukupan oksigen), komposisi bahan organik, penempatan bahan di dalam profil tanah, dan tingkat perlindungan fisik, misalnya, di dalam agregat tanah (Bruce et al., 1999). Laju dekomposisi dan pergantian bahan organik tanah/SOC utamanya tergantung pada interaksi antara biota tanah, suhu, kelembaban, dan komposisi kimia dan fisik tanah (Davidson \& Janssens, 2006; Taylor et al., 2009). Laju dekomposisi meningkat dengan meningkatnya kelembaban dan suhu tanah sehingga mempercepat hilangnya SOC. Pada budidaya pertanian, kandungan SOC umumnya menurun. Sebagian penurunan ini terjadi karena peningkatan dekomposisi SOC yang dihasilkan dari pengolahan tanah yang dikerjakan dan sebagian lainnya karena penurunan pasokan sebagai akibat dari perpindahan/kehilangan biomassa tanaman dari permukaan atas tanah (Li \& Feng, 2002).

Hasil penelitian ini mengindikasikan bahwa penurunan kandungan SOC pada T2 adalah karena tanaman jenis $S$. leprosula termasuk jenis pohon tumbuh lambat. Produktivitasnya yang rendah akan menghasilkan produksi jumlah serasah yang rendah pada lantai hutan sehingga transfer atau pasokan bahan organik/karbon organik ke dalam mineral tanah terbatas, terutama pada awal pertumbuhannya. Penurunan kandungan SOC pada plot hutan tanaman S. leprosula kemungkinan besar juga disebabkan oleh laju dekomposisi serasahnya yang tinggi (rasio
$\mathrm{C} / \mathrm{N}$ rendah). Rasio $\mathrm{C} / \mathrm{N}$ bahan organik/residu tanaman yang rendah dikenal sebagai tipe karbon labil/aktif. Tipe karbon labil dikarakterisasi dengan laju pergantian yang cepat, yaitu harian ke tahunan, dan sensitif terhadap pengelolaan lahan dan lingkungan, dan lebih cepat terdekomposisi oleh mikro organisme. Tipe ini sangat penting untuk pelepasan unsur hara dan membantu untuk mengembangkan tipe karbon/bahan organik tanah yang lambat (Gobin et al., 2011). Dalam proses dekomposisi, produk yang berbeda dilepaskan, yakni: $\mathrm{CO}_{2}$, energi, air, unsur hara tanaman, dan pembentukan senyawa karbon organik yang baru (Bot \& Benites, 2005).

Perbandingan kandungan SOC antara plot vegetasi awal/baseline vegetation (B) atau sebelum penyiapan lahan dan plot hutan tanaman Shorea leprosula setelah penyiapan lahan (T1), disajikan pada Tabel 3. Kandungan SOC di antara kedua plot (B dan T1) tidak berbeda nyata pada setiap lapisan kedalaman tanah $(p>0,05)$ namun cenderung sedikit mengalami penurunan pada kedalaman 0-10 cm pada T1 (Tabel 3, Gambar 2).

Praktik-praktik pengelolaan hutan yang mencakup metode penyiapan lahan, untuk pembentukan generasi pohon baru juga berdampak terhadap karbon tanah (Lal, 2005a; Gelman et al., 2013). Penurunan pasokan pada tahun awal penanaman, selain dekomposisi yg lebih cepat dan erosi, juga sebagai akibat perpindahan biomassa permukaan tanah pada saat penyiapan lahan/pengolahan awal (Mini \& Rao, 2011; West et al.,

Tabel(Table) 3. Perbandingan nilai rerata kandungan SOC antara plot vegetasi awal (B) dan plot hutan tanaman S. leprosula setelah penyiapan lahan (T1) pada tujuh lapisan tanah (Comparison of mean values of SOC content between baseline vegetation plot and $\mathrm{S}$. leprosula plantation plot after land preparation (T1) at seven soil layers)

\begin{tabular}{ccccc}
\hline & & \multicolumn{2}{c}{$\begin{array}{c}\text { Kandungan karbon (carbon content), } \\
\text { C }(\%), \text { rerata (mean) } \pm \text { SD }\end{array}$} & Anova \\
\cline { 3 - 5 } Kedalaman (Depths) & $\mathrm{N}$ & $\mathrm{B}$ & $\mathrm{T} 1$ & $\begin{array}{c}\text { Nilai F } \\
(\text { F- value })\end{array}$ \\
\cline { 3 - 5 } & 40 & $6,07 \pm 0,84$ & $5,85 \pm 0,82$ & 1,35 \\
$5-5$ & 40 & $4,60 \pm 0,78$ & $4,30 \pm 0,68$ & 3,46 \\
$10-20$ & 40 & $3,54 \pm 0,64$ & $3,58 \pm 0,58$ & 0,09 \\
$20-30$ & 40 & $2,70 \pm 0,41$ & $2,82 \pm 0,48$ & 5,46 \\
$30-50$ & 5 & $1,63 \pm 0,26$ & $2,08 \pm 0,33$ & 2,54 \\
$50-70$ & 5 & $1,42 \pm 0,20$ & $1,61 \pm 0,17$ & 1,60 \\
$70-100$ & 5 & $0,97 \pm 0,47$ & $1,25 \pm 0,16$ & \\
\hline
\end{tabular}

Keterangan (Remarks):

1. $* * *=\mathrm{p}<0,001$;

2. Nilai rerata di dalam kolom yang sama diikuti huruf yang berbeda adalah berbeda nyata pada taraf $5 \%$ menurut uji HSD-Tukey Kramer, $\mathrm{p}<0,05$ ) (Mean value in the same columns followed by the different letters are significantly different at $5 \%$ level according to Tukey-Krammer HSD test) 


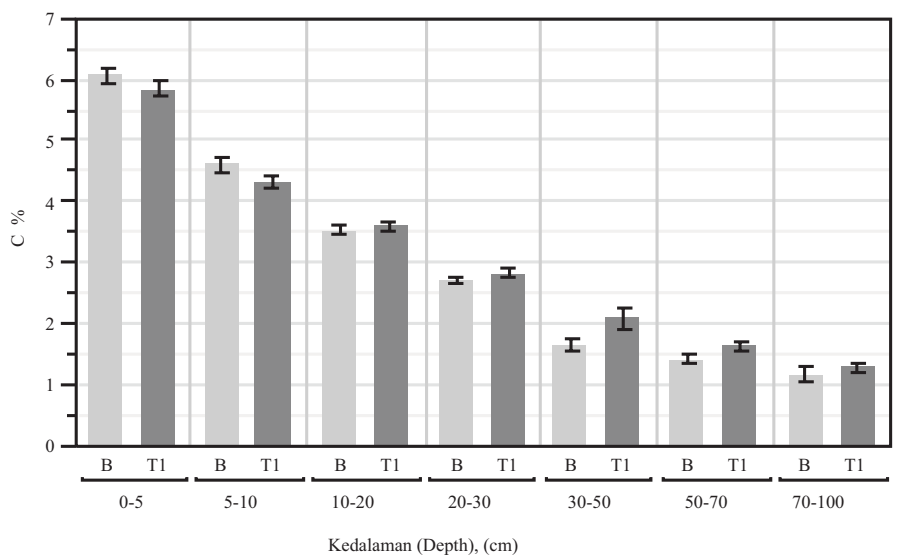

Gambar(Figure)2. Perbandingan nilai rerata kandungan SOC (C\%) antara plot vegetasi awal (B) dan plot hutan tanaman $S$. leprosula (T1) setelah penyiapan lahan pada tujuh lapisan tanah (Comparison of mean values of SOC (C\%) between baseline vegetation plot (B) and S. leprosula plantation plot after land preparation (T1) at seven soil layers)

2004). Penyiapan dan pengolahan lahan mengakibatkan bahan organik tanah/SOC hilang oleh karena gangguan fisik terhadap agregat tanah dan selanjutnya C organik menjadi tidak terlindungi, yang kemudian teroksidasi dan hilang sebagai $\mathrm{CO}_{2}$ ke atmosfer (Post \& Kwon, 2000; West et al., 2004). Pengolahan lahan dapat meningkatkan laju dekomposisi dengan tidak melindungi bahan organik yang sebelumnya terhalang ke arah degradasi oleh mikroba akibat gangguan pada struktur tanah dan perubahan porositas yang menciptakan suatu lingkungan dekomposisi yang lebih menguntungkan (Sanderman et al., 2010). Hasil penelitian ini mengindikasikan bahwa tidak ada perbedaan yang signifikan terhadap perubahan kandungan SOC sebelum dan sesudah penyiapan lahan (sebelum penanaman).

\section{B. Kerapatan Massa Tanah}

Kerapatan massa (BD) tanah pada plot hutan tanaman S. leprosula pada pengamatan pertama (T1) dan kedua (T2) disajikan pada Tabel 4. Ratarata keseluruhan $\mathrm{BD}$ tanah pada kedalaman 0 $100 \mathrm{~cm}$ berkisar antara $0,57-0,82 \mathrm{~g} / \mathrm{cm}^{3}$ pada $\mathrm{T} 1$ dan $0,67-0,86 \mathrm{~g} / \mathrm{cm}^{3}$ pada T2. BD tanah meningkat dan berbeda baik nyata maupun tidak nyata di antara lapisan tanah pada kedalaman $0-100 \mathrm{~cm}(0-5 ; 5-10 ; 10-20 ; 20-30 ; 30-50 ; 50-$ 70 ; dan 70-100 cm) dengan meningkatnya kedalaman tanah baik pada T1 maupun pada T2. BD tanah biasanya meningkat dengan kedalaman tanah karena lapisan bawah permukaan adalah lebih padat dan mempunyai sedikit bahan organik, agregasi kurang, dan penetrasi akar lebih sedikit dibandingkan dengan lapisan permukaan, oleh karena itu, mengandung lebih sedikit ruang pori (Eluozo, 2013).

Berdasarkan seri waktu, BD tanah meningkat pada kedalaman 0-30 $\mathrm{cm}$ dan berbeda nyata pada lapisan $0-5(\mathrm{p}<0,001) ; 10-20(\mathrm{p}<0,001)$; dan $20-30 \mathrm{~cm}(\mathrm{p}<0,05)$, dan cenderung sedikit meningkat walaupun tidak berbeda nyata pada lapisan 5-10 $\mathrm{cm}(\mathrm{p}>0,05)$ dan pada lapisanlapisan pada kedalaman 30-100 cm (Tabel 4, Gambar 3). Hasil penelitian ini mengindikasikan bahwa pembangunan hutan tanaman tumbuh lambat $S$. leprosula dalam periode waktu empat tahun sete-lah penyiapan lahan dan penanaman telah terjadi pemadatan tanah baik nyata maupun tidak nyata pada setiap lapisan tanah (Tabel 4).

Kerapatan massa (BD) tanah pada umumnya berkorelasi negatif dengan bahan organik tanah atau karbon organik tanah (SOC) (Weil \& Magdoff, 2004). Kehilangan C organik dari peningkatan dekomposisi akibat peningkatan suhu (Davidson \& Janssens 2006) dapat menyebabkan peningkatan $\mathrm{BD}$ tanah sehingga membuat tanah lebih rentan terhadap pemadatan melalui kegiatan pengelolaan lahan dan tekanan perubahan iklim, misalnya, dari kejadian hujan dan kekeringan dengan intensitas tinggi dan bervariasi (Birka et al., 2009). BD tanah yang tinggi merupakan indikator pada porositas tanah yang rendah dan pemadatan tanah. Hal ini berdampak terhadap kapasitas air yang tersedia, pertumbuhan akar, pergerakan udara dan air melalui tanah. Dengan mengurangi infiltrasi air ke dalam tanah, pemadatan dapat meningkatkan aliran permukaan dan erosi dari lahan miring atau tanah jenuh ke areal yang datar (Allen et al., 2010). Peningkatan pe- 
Tabel(Table) 4. Perbandingan kerapatan massa tanah pada hutan tanaman S. leprosula berdasarkan waktu pengambilan contoh pada tujuh lapisan tanah (Comparison of mean values of soil bulk density of $\mathrm{S}$. leprosula plantation based on the sampling times of seven soil layers)

\begin{tabular}{|c|c|c|c|c|}
\hline \multirow{2}{*}{$\begin{array}{c}\text { Kedalaman } \\
\text { (Depths) }\end{array}$} & \multirow[b]{2}{*}{$\mathrm{N}$} & \multicolumn{2}{|c|}{$\begin{array}{l}\text { Kerapatan tanah (Bulk density), } \\
\left.\mathrm{BD}\left(\mathrm{g} / \mathrm{cm}^{3}\right) \text {, rerata (mean }\right) \pm \mathrm{SD}\end{array}$} & \multirow{2}{*}{$\begin{array}{c}\text { Anova } \\
\text { Nilai F } \\
(F-\text { value })\end{array}$} \\
\hline & & $\mathrm{T} 1$ & $\mathrm{~T} 2$ & \\
\hline $0-5$ & 40 & $0,57 \pm 0,09(\mathrm{~d})$ & $0,67 \pm 0,11(\mathrm{c})$ & $17,48^{* * *}$ \\
\hline $5-10$ & 40 & $0,67 \pm 0,08(\mathrm{c})$ & $0,70 \pm 0,08(\mathrm{bc})$ & 3,40 \\
\hline $10-20$ & 40 & $0,69 \pm 0,07(\mathrm{bc})$ & $0,77 \pm 0,11$ (a) & $13,20^{* * *}$ \\
\hline $20-30$ & 40 & $0,73 \pm 0,06(\mathrm{ab})$ & $0,78 \pm 0,10$ (a) & $5,95^{*}$ \\
\hline $30-50$ & 5 & $0,76 \pm 0,06(\mathrm{abc})$ & $0,79 \pm 0,12(\mathrm{abc})$ & 0,29 \\
\hline $50-70$ & 5 & $0,80 \pm 0,02(a)$ & $0,82 \pm 0,05(\mathrm{ab})$ & 0,54 \\
\hline $70-100$ & 5 & $0,82 \pm 0,06(a)$ & $0,86 \pm 0,09$ (a) & 0,53 \\
\hline
\end{tabular}

Keterangan (Remarks) :

$1 . * * *=\mathrm{p}<0,001$

2. Nilai rerata di dalam kolom yang sama diikuti huruf yang berbeda adalah berbeda nyata pada taraf $5 \%$ menurut uji HSD-Tukey Kramer, $\mathrm{p}<0,05$ ) (Mean value in the same columns followed by the different letters are significantly different at $5 \%$ level according to Tukey-Krammer HSD test)

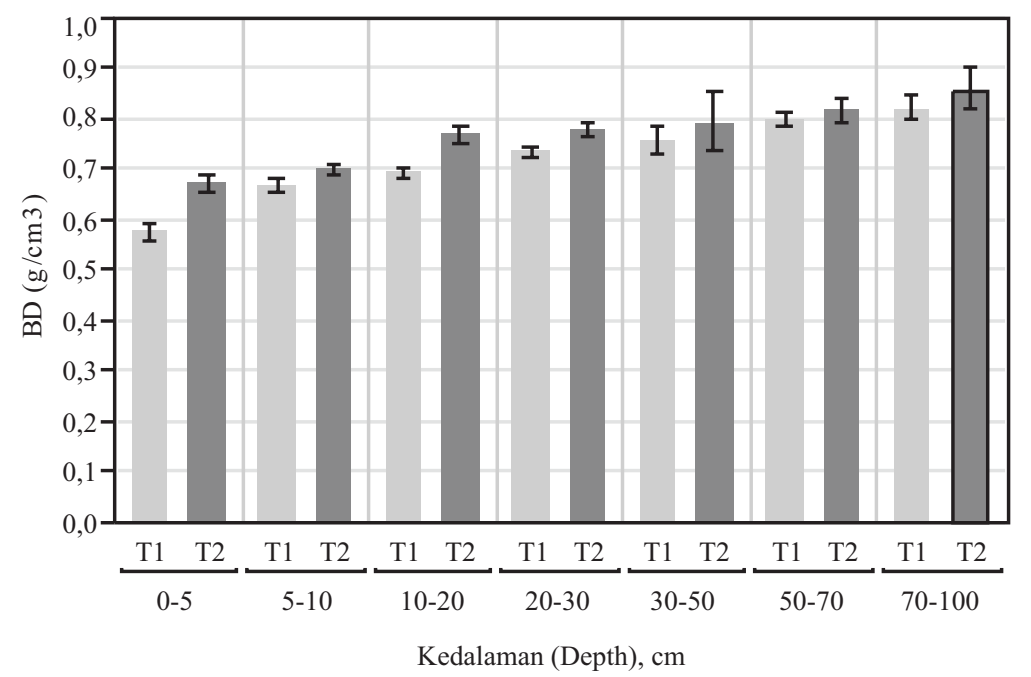

Gambar(Figure) 3. Perbandingan kerapatan massa (BD) tanah berdasarkan waktu pengambilan contoh pada tujuh lapisan tanah (Comparison of mean values of soil bulk densities (BD) based on the sampling times of seven soil layers)

madatan tanah dapat membatasi akses akar terhadap air dan unsur-unsur hara, merusak unit struktur tanah, difusi gas lambat, dan mengurangi penguraian serasah tanaman (Liao et al., 2010). Efek pemadatan tanah dapat menyebabkan penghancuran agregat tanah, yang memiliki pengaruh negatif pada struktur agregat tanah. Efek negatif pemadatan tanah pada kualitas tanah dan produksi tanaman, antara lain: menyebabkan ruang pori tanah menjadi lebih kecil; mengurangi laju infiltrasi air ke dalam tanah; menurunkan tingkat yang mana air akan menembus ke dalam zona akar tanah dan lapisan tanah; meningkatkan potensi genangan air permukaan, limpasan air, genangan tanah permukaan, dan erosi tanah; mengurangi kemampuan tanah menahan air dan udara, yang diperlukan untuk pertumbuhan dan fungsi akar tanaman; mengurangi munculnya tanaman sebagai hasil dari pengerasan tanah; menghambat pertumbuhan akar dan membatasi volume tanah yang dieksplorasi oleh akar dan mengurangi kemampuan tanaman mengambil nutrisi dan air secara efisien dari tanah; dan mengurangi potensi hasil tanaman (McKenzie, 2010). 


\section{Kerapatan dan Massa Kumulatif pada Fraksi Mineral Tanah}

Kerapatan massa fraksi mineral tanah (BDmf) pada T2 lebih tinggi daripada BDmf T1 pada setiap lapisan tanah (Tabel 5). Sementara massa kumulatif fraksi mineral tanah kumulatif (MF mass) pada $\mathrm{T} 2$ adalah lebih tinggi daripada MF mass pada T1 pada setiap kedalaman (Tabel 4). Rasio T2/T1 untuk massa kumulatif fraksi mineral tanah berkisar dari 1,05 ke 1,19 dan terendah pada kedalaman $70-100 \mathrm{~cm}$. Massa kumulatif fraksi mineral tanah pada kedalaman $0-5$; 0-10; 0-20; $0-30 ; 0-50 ; 0-70$; dan 0-100 cm pada T2 adalah setara dengan kedalaman 5,$93 ; 11,13 ; 22,19 ; 32,76 ; 53,80 ; 74,1$; dan $105,26 \mathrm{~cm}$ pada T1 secara berurutan. Perubahan massa fraksi mineral tanah ke arah yang lebih tinggi pada T2 dari T1 mengindikasikan bahwa telah terjadi pemadatan tanah setelah empat tahun (T2) perubahan tataguna lahan dari hutan sekunder menjadi hutan tanaman tumbuh lambat S. leprosula pada tipe tanah Ferralsols di Ngasuh.

Alasan pemilihan equivalent soil mass approach adalah semua hal menjadi setara. Jika contoh tanah diambil berdasarkan kedalaman tertentu (fixed layer) tanpa memperhitungkan kemungkinan terjadinya perubahan di antara dua seri pengambilan contoh tanah pada waktu yang berbeda, antara lain: pemadatan tanah, penggemburan tanah, pencucian tanah, dan lereng, yang ke semuanya mempengaruhi nilai kerapatan tanah (BD tanah), maka perhitungan simpanan SOC menjadi bias (Don et al., 2010). Apabila tanah semakin padat (BD tanah lebih tinggi), maka tanah akan me-ngandung massa yang lebih besar pada suatu kedalaman tertentu, sehingga kandung-an C-nya lebih tinggi. Kalau kedalaman yang sama digunakan sebagai dasar perhitungan, pengelolaan yang cenderung memadatkan tanah kemung-kinan akan menunjukkan peningkatan hasil yang bias terhadap jumlah simpanan SOC, sementara pengelolaan yang cenderung menggemburkan tanah (BD tanah lebih rendah) kemungkinan akan menghasilkan penurunan yang bias terhadap jumlah simpanan SOC (Sanderman et al., 2010). Jika jumlah simpanan karbon tanah dinyatakan dalam satuan kedalaman tertentu atau dibandingkan pada kedalaman tertentu dalam seri waktu yang berbeda, maka penyesuaian untuk memperhitungkan massa tanah setara akan diperlukan jika BD tanah bervariasi berdasarkan waktu (Don et al., 2007 ; Ellert \& Bettany, 1995 ; Ellert et al., 2002 ; Vanden Bygaart, 2006 ; dan Don et al., 2010). Fluktuasi BD tanah menyebabkan fluktuasi terhadap ketinggian permukaan tanah dan titik pengambilan contoh tanah. BD tanah berpengaruh pada kedalaman titik pengambilan contoh dan mempengaruhi jumlah simpanan SOC kumulatif (Wuest, 2009). Tanpa koreksi massa tanah, pengaruh perubahan tataguna lahan terhadap simpanan karbon organik tanah akan lebih rendah 28\% (Don et al., 2010).

\section{Simpanan Karbon Tanah dan Perubahan- nya}

Simpanan SOC (SOC stocks) kumulatif pada plot hutan tanaman Shorea leprosula pada pengamatan pertama (T1) dan kedua (T2) disajikan pada Tabel 6.

Tabel(Table) 5. Kerapatan dan massa kumulatif fraksi mineral tanah pada T1 dan T2 (Density and cumulative mass of soil mineral fraction at $T 1$ and $T 2$ )

\begin{tabular}{|c|c|c|c|c|c|c|c|}
\hline \multicolumn{3}{|c|}{$\begin{array}{c}\text { Kerapatan massa fraksi mineral tanah } \\
\text { (Density of soil mineral fraction/ } \\
\text { BDmf), } \\
\text { Rerata }(\text { Mean }),\end{array}$} & \multicolumn{4}{|c|}{$\begin{array}{c}\text { Massa kumulatif fraksi mineral tanah } \\
\text { (Cumulative mass of soil mineral } \\
\text { fraction/MF mass) } \\
\text { Rerata (Mean) }\end{array}$} & \multirow{2}{*}{$\begin{array}{c}\text { Ketebalan setara } \mathrm{T} 2 \text { ke } \mathrm{T} 1 \\
\text { (Equivalent thickness of } T^{2} \\
\text { to } T 1),(\mathrm{cm})\end{array}$} \\
\hline $\begin{array}{l}\text { Kedalaman } \\
(\text { Depth }) \\
\quad(\mathrm{cm})\end{array}$ & $\begin{array}{c}\mathrm{T} 1 \\
\text { (ton/ha/cm) }\end{array}$ & $\begin{array}{c}\mathrm{T} 2 \\
\text { (ton/ha/cm) }\end{array}$ & $\begin{array}{l}\text { Kedalaman } \\
\text { (Depth) } \\
\quad(\mathrm{cm})\end{array}$ & $\begin{array}{c}\mathrm{T} 1 \\
\text { (ton/ha) }\end{array}$ & $\begin{array}{c}\mathrm{T} 2 \\
\text { (ton/ha) }\end{array}$ & $\mathrm{T} 2 / \mathrm{T} 1$ & \\
\hline $0-5$ & 52 & 61 & $0-5$ & 259 & 307 & 1,19 & 5,93 \\
\hline $5-10$ & 62 & 65 & $0-10$ & 567 & 632 & 1,11 & 11,13 \\
\hline $10-20$ & 65 & 72 & $0-20$ & 1.219 & 1.353 & 1,11 & 22,19 \\
\hline $20-30$ & 70 & 74 & $0-30$ & 1.917 & 2.093 & 1,09 & 32,76 \\
\hline $30-50$ & 73 & 76 & $0-50$ & 3.337 & 3.590 & 1,08 & 53,80 \\
\hline $50-70$ & 78 & 79 & $0-70$ & 4.890 & 5.177 & 1,06 & 74,11 \\
\hline $70-100$ & 80 & 84 & $0-100$ & 7.303 & 7.688 & 1,05 & 105,26 \\
\hline
\end{tabular}


Berdasarkan seri waktu, simpanan SOC kumulatif menurun dan berbeda nyata pada kedalaman 0-5 cm $(\mathrm{p}<0,001) ; 0-10 \mathrm{~cm}(\mathrm{p}<0,01)$; dan $0-20 \mathrm{~cm}(\mathrm{p}<0,05)$, namun tidak berbeda nyata pada kedalaman $0-30 \mathrm{~cm}(p>0,05)$. Simpanan SOC kumulatif pada kedalaman $0-5$; 0-10; 0-20; dan 0-30 cm menurun sebesar 2,99; 3,05 ; 3,35 ; dan 3,0 ton/ha, dengan laju kehilangan sebesar 0,$78 ; 0,80 ; 0,87$; dan 0,78 ton $\mathrm{C} /$ ha/tahun $(4,73 ; 2,61 ; 1,58$; dan $1,04 \%$ per tahun dari $\mathrm{T} 1$ ) atau setara dengan emisi $\mathrm{CO}_{2}$ yang dilepas dari tanah ke atmosfer sebesar 2,86; 2,94; 3,19 ; dan 2,86 ton $\mathrm{CO}_{2} / \mathrm{ha} /$ tahun secara berurutan (faktor konversi $\mathrm{C}$ ke $\mathrm{CO}_{2}=3,67$ ). Sementara pada kedalaman 0-50; 0-70; dan 0-100 cm, simpanan SOC kumulatif tidak berbeda secara statistik $(p>0,05)$ di antara kedua seri waktu pengukuran (T1 dan $\mathrm{T} 2$ ) namun cenderung mengalami peningkatan, yaitu sebesar 7,49; 11,$80 ; 16,70$ ton $\mathrm{C} / \mathrm{ha}$, dengan laju akumulasi/sekuestrasi sebesar 1,$96 ; 3,08$; dan 4,36 ton $\mathrm{C} /$ ha/tahun $(1,87 ; 3,08 ; 2,71 \%$ per tahun dari T1) secara berurutan (Tabel 6, Gambar 4).

Hasil penelitian mengindikasikan bahwa penurunan simpanan karbon organik tanah yang signifikan pada kedalaman $0-20 \mathrm{~cm}$ pada hutan tanaman lambat tumbuh $S$. leprosula pada tipe tanah Ferralsols di Ngasuh adalah karena transfer karbon organik yang rendah ke mineral tanah sebagai akibat jumlah pasokan bahan organik/ serasah yang rendah dari lantai hutan dan laju dekomposisi serasahnya yang tinggi (rasio $\mathrm{C} / \mathrm{N}$ rendah). Kehilangan karbon dari tanah hasil dari dekomposisi dan konversi karbon pada residu tanaman dan bahan organik tanah menjadi $\mathrm{CO}_{2}$
(Baldock, 1999). Hasil penelitian menunjukkan bahwa perubahan simpanan SOC secara signifikan terbatas pada kedalaman $0-20 \mathrm{~cm}$. Perubahan simpanan SOC pada perubahan tataguna lahan atau pengelolaan lahan terutama pada kedalaman 10 atau $30 \mathrm{~cm}$ pada sebagian besar tanah (Knowles \& Singh, 2003; Dalal et al. 2005). Untuk pengukuran atau estimasi simpanan SOC, IPCC (2006) merekomendasikan pengambilan contoh tanah pada kedalaman 30 $\mathrm{cm}$. Simpanan karbon pada lapisan permukaan tanah adalah yang paling labil dan, oleh karena itu, lebih peka terhadap perubahan (alteration) setelah perubahan penutupan lahan (Cerri et al.,1999).

Praktik-praktik pengelolaan terbaik untuk membangun simpanan karbon di dalam tanah pada dasarnya adalah praktik-praktik pengelolaan yang meningkatkan masukan bahan organik ke dalam tanah, dan/atau menurunkan laju dekomposisi bahan organik tanah (Batjes, 1999). Sebaliknya, penurunan jumlah kandungan C pada suatu gudang (pool) di dalam tanah (SOC stock) disebabkan oleh berbagai faktor termasuk: penurunan jumlah biomassa (di atas dan di bawah tanah) yang dikembalikan ke dalam tanah; perubahan kelembaban tanah dan kondisi suhu yang meningkatkan laju dekomposisi bahan organik tanah; tingginya keteruraian residu tanaman karena perbedaan rasio $\mathrm{C} / \mathrm{N}$ dan kandungan lignin; gangguan yang dipengaruhi oleh pengolahan tanah; penurunan aggregasi tanah dan berkurangnya perlindungan fisik pada bahan organik tanah; dan peningkatan erosi tanah (Lal, 2005a).

Tabel (Table) 6. Perbandingan jumlah simpanan karbon organik tanah pada hutan tanaman S. leprosula berdasarkan waktu pengambilan contoh pada tujuh kedalaman tanah (Comparison of soil organic carbon stocks of $\mathrm{S}$. leprosula plantation based on sampling times of seven soil depth)

\begin{tabular}{|c|c|c|c|c|c|}
\hline \multirow[t]{2}{*}{$\begin{array}{l}\text { Kedalaman } \\
(\text { Depths }), \mathrm{cm}\end{array}$} & \multirow[b]{2}{*}{$\mathrm{N}$} & \multicolumn{2}{|c|}{$\begin{array}{c}\text { Simpanan SOC } \\
(\text { SOC stock }), \\
\text { Rerata }(\text { Mean }) \pm \mathrm{SD},(\text { ton } / \text { ha })\end{array}$} & \multirow[t]{2}{*}{$\begin{array}{l}\text { ANOVA, } \\
\text { Nilai F }) \\
(F \text {-value })\end{array}$} & \multirow{2}{*}{$\begin{array}{c}\text { Laju kehilangan SOC (Rate } \\
\text { of SOC loss), [ton/ha/tahun } \\
(y r)] \\
\Delta(\mathrm{T} 2-\mathrm{T} 1) / 4\end{array}$} \\
\hline & & $\mathrm{T} 1$ & $\mathrm{~T} 2$ & & \\
\hline $0-5$ & 40 & $16,50 \pm 1,42$ & $13,51 \pm 2,99$ & $32,59^{* * *}$ & $-0,78$ \\
\hline $0-10$ & 40 & $30,62 \pm 2,39$ & $27,57 \pm 4,88$ & $12,64^{* *}$ & $-0,80$ \\
\hline $0-20$ & 40 & $55,23 \pm 5,02$ & $51,88 \pm 7,90$ & $5,12^{*}$ & $-0,87$ \\
\hline $0-30$ & 40 & $75,68 \pm 6,83$ & $72,68 \pm 10,49$ & 2,29 & ns \\
\hline $0-50$ & 5 & $104,54 \pm 6,25$ & $112,03 \pm 17,90$ & 0,72 & ns \\
\hline $0-70$ & 5 & $130,23 \pm 6,74$ & $142,03 \pm 18,59$ & 1,53 & ns \\
\hline $0-100$ & 5 & $160,87 \pm 12,04$ & $177,57 \pm 1,42$ & 2,31 & ns \\
\hline
\end{tabular}




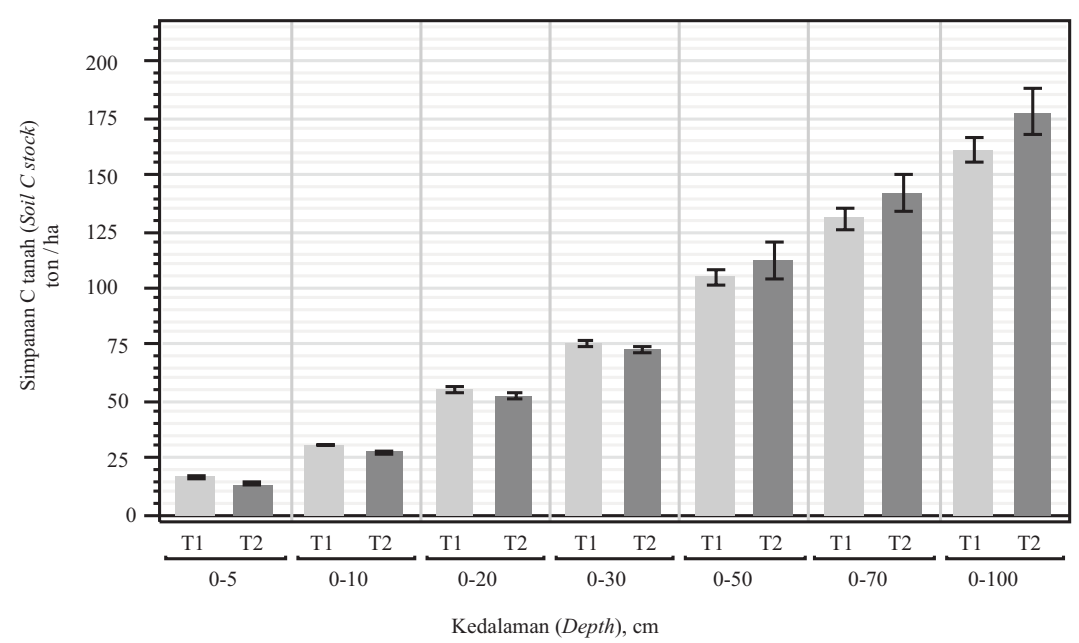

Gambar(Figure) 4. Perbandingan nilai rerata simpanan C tanah berdasarkan waktu pengambilan contoh pada tujuh lapisan tanah (Comparison of mean values of soil C stock based on the sampling times of seven soil layers)

Jumlah karbon organik yang hilang pada tanah yang dibudidayakan akan tergantung pada tipe tanah dan praktik-praktik pengelolaan yang berbeda (Salimon et al., 2009). Tipe tanah sangat terlapuk Ferralsols melepaskan SOC lebih banyak setelah pengolahan lahan dibanding tipe tanah lainnya. Tanah Ferralsols didominasi oleh liat aktivitas rendah (low activity clays) dan menyediakan permukaan mineral yang kurang untuk perlindungan fisik dan stabilisasi terhadap SOC (Don et al., 2010). Pada tanah sangat terlapuk, umumnya tanah kehilangan banyak unsur hara karena pencucian yang berlebihan (excessive leaching). Biasanya, kegiatan penyiapan lahan dilakukan untuk membersihkan lahan guna penanaman dengan cara tebang habis. Sayangnya, kegiatan ini dapat memiliki efek negatif pada penyimpanan karbon secara keseluruhan, sebagai akibat pemindahan sisa-sisa tebangan (debris) (Gershenson et al., 2011). Sebagian besar metode penyiapan lahan menyebabkan gangguan besar terhadap tanah dengan tidak melindungi/memapar lapisan mineral dan pencampuran lapisan-lapisan tanah yang berbeda. Hal Ini merangsang dekomposisi bahan organik tanah dan unsur-unsur hara dilepaskan. Selanjutnya, peningkatan respirasi tanah dapat menurunkan jumlah simpanan karbon tanah. Beberapa studi menunjukkan bahwa hilangnya $\mathrm{C}$ meningkat dengan intensitas gangguan pada tanah. Namun, karena penyiapan lahan juga meningkatkan produksi biomassa dengan mendukung pertum- buhan bibit, efek keseluruhan mungkin menyeimbangkan atau bahkan lebih besar daripada kehilangan SOC ketika melihat pada ekosistem keseluruhan (Gelman et al., 2013).

Penurunan simpanan SOC pada lapisan atas permukaan tanah kemungkinan besar lebih disebabkan oleh faktor penyiapan lahan dengan sistem tebang habis sehingga menyebabkan gangguan besar terhadap tanah lapisan atas. Kandungan bahan organik cenderung menurun ketika fraksi-fraksi organik lebih tidak terlindungi dari dekomposer sehubungan dengan pengolahan dan praktik-praktik pengelolaan tanah (Salimon et al., 2009). Erosi merupakan faktor utama yang mempengaruhi simpanan SOC yang secara langsung terkait dengan pembukaan dan penggunaan lahan (Van Noordwijk et al., 1997). SOC dapat menjadi hilang sebagai akibat erosi angin dan air oleh karena pemindahan lapisan atas tanah (topsoil) dan kerentanan lapisan bawah tanah (subsoil) terhadap suhu yang lebih tinggi (Liddicoat $e t$ al., 2010). Pengolahan lahan yang ekstensif dapat memecah agregat tanah yang mengurangi kekuatan tanah, yang dapat meningkatkan erosi (Lal, 2005b). Bahan organik mengikat mineral tanah, khususnya partikel liat, suatu proses yang lebih melindungi karbon (Von Lützow et al., 2006). Keberadaan bahan organik memberikan kekuatan kohesif terhadap tanah dan meningkatkan kesuburan tanah, pergerakan air, dan tahan terhadap erosi (Victoria et al., 2012). 
Praktik-praktik pengolahan tanah mempunyai pengaruh khusus terhadap keberadaan $\mathrm{C}$ tanah karena kegiatan tersebut mempengaruhi dinamika $\mathrm{C}$ secara langsung maupun tidak langsung. Praktik pengolahan lahan, yang membalikkan atau mengganggu permukaan tanah secara signifikan dapat mengurangi SOC (Lal, 1989). Sebaliknya, praktik-praktik tanpa pengolahan dalam jangka panjang atau pengurangan sistem pengolahan pada tanah menunjukkan peningkatan kandungan SOC pada lapisan permukaan tanah sebagai akibat dari berbagai faktor yang saling berinteraksi, seperti peningkatan kembali residu, kurangnya pencampuran dan gangguan pada tanah, kadar air tanah yang lebih tinggi, pengurangan suhu tanah permukaan, peningkatan jumlah pertumbuhan akar dan aktivitas biologis, dan penurunan resiko erosi tanah (Lal, 1989; Blevins \& Frye, 1993).

\section{KESIMPULAN DAN SARAN}

\section{A. Kesimpulan}

1. Simpanan karbon organik tanah pada hutan tanaman lambat tumbuh Shorea leprosula Miq pada tipe tanah sangat terlapuk Ferralsols di Ngasuh menurun dengan menurunnya pasokan bahan organik (serasah) dan laju dekomposisi serasahnya yang tinggi.

2. Simpanan karbon organik tanah kumulatif di bawah tegakan S. leprosula umur empat tahun pada kedalaman 0-20 cm mengalami penurunan yang signifikan sehingga berkontribusi sebagai sumber emisi, yaitu sebesar 3,35 ton/ ha dari 55,23 ke 51,88 ton $\mathrm{C} / \mathrm{ha}$, dengan laju kehilangan sebesar 0,87 ton $\mathrm{C} /$ ha/tahun $(1.58 \%$ per tahun), atau setara dengan emisi karbon dioksida $\left(\mathrm{CO}_{2}\right)$ ke atmosfer sebesar 3,19 ton $\mathrm{Co}_{2}$ /ha/tahun dalam periode waktu empat tahun pertama setelah penanaman.

\section{B. Saran}

Dalam rangka peningkatan dan konservasi karbon organik tanah, pembangunan hutan tanaman khususnya jenis pohon tumbuh lambat harus mempertimbangkan sistem pengelolaan hutan berdasarkan persyaratan tumbuh yang sesuai untuk menghindari penurunan simpanan karbon organik tanah terutama pada awal pertumbuhannya.

\section{DAFTAR PUSTAKA}

Akbarinia, M., Haghdoost, N., Mohsen, S. \& Hosseini, M. (2012). Growth and biomass production of lowland forest plantations in north of Iran. Scholars Research Library. Archives of Applied Science Research, 2012, 4 (1):595-604.

Allen, D.E., Pringle, M.J., Page, K.L., \& Dalal, R.C. (2010). A review of sampling designs for the measurement of soil organic carbon in Australian grazing lands. The Rangeland Journal 32, 227246 (CSIRO PUBLISHING).

Baldock, J. (1999). Building soil carbon for productivity and implications for carbon accounting, CSIRO Land and Water, Adelaide, SA. Agribusiness Crop Updates 2009.

Baldock J.A., \& Skjemstad, J.O. (1999). Organic soil carbon/soil organic matter. In: 'Soil analysis: An interpretation manual'. (Eds KI Peverill, Sparrow, L.A., Reuter, D.J.) pp. 159-170. Collingwood, Victoria: CSIRO Publishing.

Batjes, N.H. (1996). Total carbon and nitrogen in the soils of the world. European Journal of Soil Sci.47(2), 151-163.

Batjes, N.H. (1999). Management option for reducing $\mathrm{CO}_{2}$ concentration atmosphere by increasing carbon sequestration in soil. Report 410-200031, Dutch National Research Programme on Global Air Pollution and Climate Change and Technical Paper 30. International Soil Reference and Information Centre, Wagenigen.

Bird, S.B., Herrick, J.E., \& Wander, M.M. (2001). Exploiting heterogeneity of soil organic matter in rangelands: Benefits for carbon sequestration. In: 'The potential of U.S. grazing lands to sequester carbon and mitigate the greenhouse effect'. (Eds Follet, R. F., Kimble, J.M. and Lal, R.). pp. 121138. (CRC Press: Boca Raton, FL).

Blevins, R.L., \& Frye, W.W. (1993). Conservation tillage: An ecological approach to soil management. Adv. Agron. 51:3378.

Bruce, J.P., Frome, M., Haites, E., Joanne, H., Lal, R., and Faustian, K. (1999). Carbon sequestration in soils. Journal of Soil and Water Conservation, p. 382-389.

Cerri, C.C., Bernoux, M., Arrouays, D., Feigl, B.J. \& Piccolo, M.C. (1999). Carbon stock in soil of brazilian Amazon. In: Lal, R., Kimble, J.M. \& Steward, B.A. (Eds). Global climate change and tropical ecosystems (Advance in Soil Science). Boca Raton: CRC, p. 33-50. 
Chen, C.R., Xu, Z.H., \& Mathers, N.J. (2004). Soil carbon pools in adjacent natural and plantation forests of subtropical Australia. Soil Sci. Soc. Am.J. 68: 282291.

Dalal, R.C., Steward, B.P., Krull, E., \& Wang, W.J. (2005). Total organic matter and its labile pools following mulga (Acacia aneura) clearing for pasture development and cropping 1 . Total and labile carbon. Australian Journal of Soil Research 43, 13-20.

Davidson, E.A., \& Janssens, I.A. 2006. Suhue sensitivity of soil carbon decomposition and feedbacks to climate change. Nature 41:12-15.

Don, A., Schumacher, J., \& Freibauer, A. (2010). Impact of tropical land-use change on soil organic carbon stocks - a meta-analysis. Global Change Biology 17, 4 : 1658 - 1670.

Don, A., Schumacher, J., Scherer-Lorenzen, M., Scholten, T., \& Schulze, E.D. (2007). Spatial and vertical variation of soil carbon at two grassland sites - Implications for measuring soil carbon stocks. Geoderma 141, 272-282.

Ellert, B.H., Janzen, H.H., \& Entz, T. (2002). Assessment of a method to measure temporal change in soil carbon storage, Soil Sci. Soc. Am. $J ., 66,1687-1695$.

Ellert, B.H., \& Bettanym, J.R. (1995). Calculation of organic matter and nutrients stored in soils under contrasting management regimes. Can. J. Soil. Sci. 75, 529-538.

Eluozo, S.N. (2013). Predictive model to monitor the rate of bulk density in fine and coarse soil formation influenced variation of porosity in coastal area of port harcourt. American Journal of Engineering Science and Technology Research Vol. 1, No. 8, pp: 115-127.

Entry, J.A., \& Emmingham, W.H. (1998). Influence of forest age on forms of carbon in Dauglas-fir soils in the Oregon Coast Range. Can. J. For. Res. 28: 390 - 395 .

Eswaran, H., Berg, E.V.D., \& Reich, P. (1993). Organic carbon in soils of the world. Soil Science Society America Journal 57, 192-194.

FAO/ISRIC/ISSS. 1998. World reference base for soil resources. World Soil Resources Report No. 84. FAO, Rome.

Gelman, V., Hulkkonen, V., Kantola, R., Nousiainen, M., Nousiainen, V., \& Poku-Marboah, M. (2013). Impacts of forest management practices on forest carbon. HENVI Workshop: Interdisciplinary approach to forests and climate Change. Helsinki University Centre for Environment, HENVI University of Helsinki. 8.4.2013.
Gershenson, A., Barsimantov, J., \& EcoShift Consulting. (2011). Accounting for Carbon in Soils. Climate Action Reserve - Forest Project Protocol White Papers in Duke University Durham, North Carolina.

Gifford, R.M., \& Roderick, M.L. (2003). Soil carbon stocks and bulk density: spatial or cumulative mass coordinates as a basis of expression? Global Change Biol. 9, 1507-1514.

Govers, G., Merckx, R., Van Oost, K., \& van Wesemael, B. (2013). 'Soil organic carbon management for global benefits: a discussion paper', paper presented at the Workshop 'Soil Organic Carbon Benefits: a Scoping Study', 10th-12th September 2012, Nairobi. Workshop organised by the Scientific and Technical Advisory Panel of the Global Environmental Facility.

IPCC. (2006). IPCC guidelines for national greenhouse gas inventories. Vol 4: Agriculture, Forestry and Other Land Use.' (Eds. Eggleston, S., Buendia, L., Miwa, K., Ngara, T., \& Tanabe, K. IGES: Japan.

Jandl, R., Lindner, M., Vesterdal, L., Bauwens, B., Baritz, R., Hagedom, F. et al. (2007). How strongly can forest management influence soil carbon sequestration? Geoderma 137, 253268.

Jobbagy, E.G., \& Jackson, R.B. (2000). The vertical distribution of soil organic carbon and its relation to climate and vegetation. Ecol Appl 10 (2) : 423-436.

Kaul, M. (2010). Carbon budgets and carbon sequestration potential of Indian Forests. Unpublished. Thesis. Submitted in fulfilment of the requirements for the degree of doctor at Wageningen University.

Knowles, T.A., \& Singh, B. (2003). Carbon storage in cotton soils of northern New South Wales. Australian Journal of Soil Research 41, 889903

Lal, R. (1989). Conservation tillage for sustainable agriculture: tropics vs. temperate environments. Adv. Agron. 42: 186-197.

Lal, R. (2005a). Soil carbon sequestration in natural and managed tropical forest ecosystems. Copublished simultaneously. Journal of Sustainable Forestry (Food Products Press, an imprint of The Haworth Press, Inc.) Vol. 21, No. 1, pp. 1-30; and: Environmental Services of Agroforestry Systems (ed: Florencia Montagnini) Food Products Press, an imprint of The Haworth Press, Inc., pp. 1-30.

Lal, R. (2005b). Soil erosion and carbon dynamics. Soil \& Tillage Research 81, 137-142. 
Liao, C., Luo, Y., Fang, C., \& Li, B. (2010). Ecosystem carbon stock Influenced by plantation practice: Implications for planting forests as a measure of climate change mitigation. PLOS ONE 5(5): e10867.

Liddicoat, C., Schapel, A., Davenport, D., \& Dwyer, E. (2010). Soil carbon and climate change. For the Sustainable Systems Group, Agriculture, Food and Wine, Primary Industries and Resources SA, PIRSA Discussion Paper.

Li, X., \& Feng, Y. (2002). Carbon sequestration potentials in agricultural soils. AIDIS-CANADA Environmental Project. Alberta Research Council Inc. (ARC) and AIDIS as the Latin American partner).

Lorenz, K. \& Lal, R. (2005). The depth distribution of soil organic carbon in relation to land use and management and the potential of carbon sequestration in subsoil horizons. Elsevier. Advance in Agronomy Vol. 88, 35-66.

Madeira, M.V., Fabiao, A., Pereira, J.S., Araujo, M.C., \& Ribeiro, C. (2002). Changes in carbon stocks in Eucalyptus globulus Labill. plantations induced by different water and nutrient availability. Forest Ecology and Management 171,75-85.

McKenzie, D. (2010). Soil carbon sequestration under pasture In southern Australia. 'Dairy Australia' Soil Carbon Report. Prepared for Dairy Australia Project MCK13538. pp.43.

Mendham, D.S., O'Connell, A.M., \& Grove, T.S. (2003). Change in soil carbon after land clearing or afforestation in highly weathered lateritic and sandy soils of south-western Australia. Agriculture, Ecosystems \& Environment. Volume 95 Issue 1, Pages 143-156.

Mini, E.R., \& Rao, Y.S. (2011). An evaluation of soil carbon sequestration in teak and eucalypt plantations. NeBIO Vol. 2 No. 3,9-11.

Moreno, F.H. (2004). Soil carbon dynamics in primary and secondary tropical forests in Colombia. Unpublished. PhD Dissertation. Florida International University. pp.193.

Moura-Costa, P. 1996. Tropical forestry practices for carbon sequestration. In: Dipterocarp forest ecosystems - Towards Sustainable Management. Schulte, A. \& Schone, D. (Eds.). World Scientific. pp. 308-334. Singapore.

Ohta, S. (2001). Outlined procedure of soil survey and soil sampling (Draft). Carbon Fixing Forest Management Project. Unpublished. Japan International Cooperation Agency and Forestry Research and Development Agency. Indonesia: Ministry of Forestry.
Post, W.M., Emanuel, W.R., Zinke, P.J. \& Stangenberger, A.G. (1982). Soil carbon pools and world life zones. Nature 298, 156-159.

Post, W.M., \& Kwon, K.C. (2000). Soil carbon sequestration and land-use change : Processes and potential. Global Change Biology 6, 317328.

Pribyl, D.W. (2010). A critical review of the conventional SOC to SOM conversion factor. Geoderma 156, 75-83.

Salimon, C.I., Wadt, P.G.S., \& Alves, S.S. (2009). Decrease in Carbon stocks in an oxisol due tue land use and cover change in southwestern Amazon. Ambi-Agua, Taubate, v.4.n.2, p.5765.

Sall, J., Creighton, L., \& Lehman, A. (2005). JMP start statistics. A guide to statistics and data analysis using JMP and JMP in Software (3th ed.). Thomson Learning Academic Resource Center.

Sanderman, J., Farquharson, R., \& Baldock, J. (2010). Soil carbon sequestration potential: A review for Australian agriculture. CSIRO Land and Water. pp.76.

Siregar, C.A., Siringoringo, H.H., \& Hatori, H. (2003). Analysis of soil carbon accumulation of Shorea leprosula plantation in Ngasuh, West Java. Buletin Penelitian Hutan 634 : p. 79-92.

Soil Survey Staff. (1999). Keys to soil taxonomy. USDA Natural Resources Conservation Service, Washington DC.

Taylor, L.L., Leake, J.R., Quirk, J., Hardy, K., Banwart, S.A., \& Beerling, D.J. (2009). Biological weathering and the long-term carbon cycle: integrating mycorrhizal evolution and function into the current paradigm. Geobio$\log$. 7, 171-191.

The Word Bank. (2012). Carbon sequestration in agricultural soils. Agriculture and Rural Development. Report Number 67395-GLB. The World Bank, Washington.

Toriyama, J., KatoT., Siregar, C.A., Siringoringo, H.H., Ohta, S., \& Kiyono, Y. (2011). Comparison of depth- and mass-based approaches for estimating changes in forest soil carbon stocks: A case study in young plantations and secondary forests in West Java, Indonesia. Elsevier. Forest Ecology and Management 262: p. $1659-1667$.

Updegraff, K., Baughman, M.J., \& Taff, S.J. (2004). Environmental benefits of cropland conversion to hybrids poplar: Economic and policy considerations. Biomass and Bioenergy 27, 411-428. 
Van den Bygaart, A.J. (2006). Monitoring soil organic carbon stock changes in agricultural landscapes: Issues and a proposed approach. Can. J. Soil Sci. 86, 451-463.

Van Noordwijk, M., Cerri, C., Woomer, P.L., Nugroho, K., \& Bernoux, M. (1997). Soil carbon dynamics in the humid tropical forest zone. Geoderma 79, 187-225.

Victoria, R., Banwart, S., Black, H., Ingram, J., Joosten, H., Milne, E. et al. (2012). The benefit of soil carbon. $\underline{\text { In }}$ : Managing soils for multiple economic, societal and environmental benefits. UNEP Year Book 2012.

Von Lutzow, M., Kogel-Knaber, I., Ekschmitte, K., Matzner, E., Guggenberger, G., Marschner, B. et al. (2006). Stabilization of organic matter in temperate soils: mechanisms and their relevance under different soil conditions -A review. European Journal of Soil Science 57, 426-445.

Weil, R.R., \& Magdoff, F. (2004). Significance of soil organic matter to soil quality and health. In: Weil, R.R., Magdoff, F. (eds) Soil organic matter in sustainable agriculture. Florida: CRC press, pp 1-43.

West, T.O., Marland, G., King, A.W., \& Post, W.M. (2004). Carbon management response curves: Estimates of temporal soil carbon dynamics. Environmental Management Vol. 33 No. 4, pp. 507-518.

Wuest, S.B. (2009). Correction of bulk density and sampling method biases using soil mass per unit area. SSSAJ Volume 73: Number 1. 